https://doi.org/10.48009/2_iis_2010_208-218

\title{
LINKING THE NEW DIGITAL DIVIDE: A CURRICULUM FOCUS FOR MOBILE INDEPENDENT BUSINESS UNITS
}

\author{
Daniel T. Norris, McNeese State University
}

\begin{abstract}
A thorough literature review forms a picture of near full adoption of m-ICT around the world. The rush of business computing toward mobile information and communication technology (m-ICT) is forcing a reconceptualization of knowledge workers as independent business units (Malone \& Laubacher, 1998). That picture also reveals that m-ICT as a business tool is poorly understood by both end users and academia. In business specific education there is little attention being given to how to incorporate these sweeping changes. Incorporation of a mobile technology focused curriculum into four-year business curriculums can bridge this rapidly increasing skills gap - the new digital divide between professionals who can effectively and efficiently use m-ICT and those who cannot. This paper presents a model upon which an m-ICT focused curriculum can be sturdily based and that promotes the flexibility and innovation inherent in mobile technology.
\end{abstract}

\section{INTRODUCTION}

\section{Global Adoption and Mobile Feature Growth}

The presence of mobile information communication technologies (m-ICT) in both developed and developing economies has substantially changed the way humans communicate (Al-Qirim, 2006). There is a great deal of research on how mobile technologies have changed our lives, but there is little on how mobile technology changes the way information is managed. M-ICT offers much more than a convenient way of making phone calls. The vast and rapid adoption of $\mathrm{m}$-ICT portends significant changes in computing behaviors and the ways in which business problems will be solved (Computer Weekly, 2002; Hoffman \& Blake, 2003). This paper proposes a proactive curricular strategy that addresses changing business practices in human resource management, personal productivity, telecommuting, remote data acquisition, and skills unique to $\mathrm{m}$-ICT devices.

M-ICT tools are an evolutionary off-shoot of desktop computing or personal computers (PCs) 0. For the purposes of this paper m-ICT hardware includes cellular phones, hand-held devices with broadband network cards, personal digital assistants (PDA) and laptops and all the features that make these machines so powerful as data management tools. These features include location awareness, GPS sensing, remote appliance controlling, pervasive availability, and online transaction abilities (Constantiou, Damsgaard, \& Knutsen, 2007). With software downloads (commonly referred to as "apps") and a high degree of customizability the range of capabilities of mobile devices are nearly unlimited (Mearian, 2008). The open source Android project is putting mobile application design in the hands of millions of amateur programmers and is expected to push the boundaries that rigid proprietary systems have applied to mobile systems. This will create new features, thus new markets and new business paradigms that will take the end-user farther from their desktop machines (Mearian, 2008).

This potential new world is only possible if m-ICT devices are wide spread. Gartner predicts that the wireless market penetration in North America will grow to 84.8 percent in 2009 (Hart, 2005). Historical growth tends would seem to support the prediction. Worldwide sales of mobile phones surpassed 1.15 billion units in 2007, a 16 per cent increase from 2006 sales of 990.9 million, according to Gartner, Inc (Winter, 2008). In the case of highfunction phones called Smart phones, 2007 shipments were strong growing $44 \%$ over 2006 to 24.5 million units (Cozza, 2007). A report from Informatics Research (2008) states "Sales of mobile data cards, which enable broadband access in laptops via a service provider's mobile data network, are forecast...to nearly quadruple between 2007 and 2011, when they will reach $\$ 2.9$ billion" (Webb, 
2008, p. 3). This growth suggests that m-ICT is becoming, or already has become, embedded into the daily technology use patterns of people around the globe.

Dulaney, Hart, Jones, \& Basso (2008) summarize the strength of mobile telephony growth as defying "the economic slowdown, showing minimal effects of the downturn" (p. 1) going so far as to predict that such growth "will entrench mobile telephony as a basic human necessity" (p. 1). M-ICT devices have diffused past the early adopter stage and are, according to a Mintel (2007) research report, possibly in the late adopter stage (See Rogers, 1983 for explanation of adoption stages).

Feature growth coupled with global market penetration marks a significant turn in end-user computing habits. However, increased consumer adoption is not necessarily indicative of productive and efficient end-user utilization. For example Mintel (2005) indicates that the vast majority of business end-users say they use their mobile phones predominantly for personal reasons. Another incongruity is that today's mobile phones “...have the capabilities in terms of hardware and processing power and network connectivity that desktop computers had a few years ago. These devices clearly have desktop mobile computing capabilities but yet we're not using them this way" (Mearian, 2008, p. 1). Mobile phones have long stopped being a device that people merely use to make phone calls. They are now complex communication devices that support: text messaging, e-mail, instant messaging, and Internet browsing. Speaking to the more personal side, today's mobile phones can also be a camera, MP3 player, video recorder, video player, and a navigation device, as well as a fashion statement. In the future, Gartner predicts, we will see:

The use of mobile phones to communicate with and control devices linked to home networks, and as remote entertainment systems attached to home networks. They may not be the only devices performing these functions, but some consumers will expect to be able to communicate with their digital home from afar for monitoring and control purposes, particularly for security (Brown, 2006, p. 2).

\section{The Millennial Effect on Business Behaviors}

The intended market for this plethora of mobile capabilities are a population known as Millennials. People born after 1983 have always known computers and were raised in a constantly connected world (Sherry \& Fielden, 2005). This human resource group is unique as they possess behavioral attributes that seem to result from technology being so much a part of their lives. Millennials expect to have constant access to computers, the internet, cell phones, and PDAs. These connected young people prefer the interactive to the passive, and being online to watching television (Horrigan, 2007). The technology-based lifestyle of millennials has introduced changing workplace attitudes. A Pew Internet and American Life (2006) study suggests five new work place mindsets.

1. Fast-paced technologies, entertainment technologies, such as video games, have shortened attention spans and changed their idea of how to learn.

2. They are technologically literate but not necessarily media literate or business information savvy.

3. They have new ideas of property and privacy, which sometimes conflict as they weigh information accessibility with the security of their financial identity.

4. They are prone to ranking and rating as a way of conveying approval of products, people, and situations.

5. They blur the boundaries between personal and business, leisure and work (Raine, 2006)

"Millennials outpace older Americans in virtually all types of internet and cell use. They are more likely to have their own social networking profiles, to connect to the internet wirelessly when away from home or work, and to post video of themselves online" (Pew Research Center, 2010, February, p. 25). The effects of the Millennial generation characteristics is already affecting job design in high turnover industries such as retail where there is a growing paradigm shift from passive to active employees who 
craft their jobs, organizational roles, and organizational identity (Kim, Knight, \& Crutsinger, 2009). In restaurants and other parts of the hospitality sector which are traditionally high staff turnover businesses, innovative managers are offering flexible scheduling options that can be done from a mobile web environment (Oronsky \& Chathoth, 2007). Research (Shaw \& Fairhurst, 2008) indicates that technology rich business environments offer process improvement and employee retention opportunities. Through case study and literature review they concluded that businesses that offer audio-visually rich training, multi-tasking challenges which provide technologically enhanced collaborative avenues for organizational contribution and instant feedback channel will have better retention rates and be in an improved position to adopt new business models (Shaw \& Fairhurst, 2008).

\section{Changing Business Technologies Demand New Skills}

Technology has changed business and personal lives. The circle now completes back upon itself as the generation changed by technology brings technological expectations into the work place. Peter Drucker (1994) wrote in The Age of Social Transformation that an understanding of computer technology is necessary for survival of the knowledge worker in the burgeoning knowledge economy. Drucker's (1994) writing envisioned the PC as a driver of a new era in which the skills of knowledge creation and management are fundamental to business survival. The mobile phone is now on the verge of having a similar impact on business.

In order to fully grasp the enormity of the pending change in the business behavior generated by m-ICT tools, consider what the introduction of the PC has wrought in terms of disruption. Ponder for a moment this oversimplified summary of events since the PC entered our lives. Just as the PC's ability to manipulate data created a knowledge economy, the ready accessibility of PCs drove a number of innovations which in turn contributed to an ever increasing speed of change. Expanding information access pushed new business models and fostered competition (Castells, 2001). The increasing complexity and capability of the PC and its ability to house huge volumes of information, required the formation of information management systems (Pearlson \& Saunders, 2004). These systems fostered more efficient business management through compartmentalization of information (Pearlson \& Saunders, 2004). Networking technologies such as packet switching and internet protocols provided global accessibility to business information and helped to create a 24 hour business day (H. Smith \& Fingar, 2003).

As a result of the increased dependence of connected business systems communication with all data points, whether technological or human, has become crucial. The ubiquity of these connections has blended private and professional activities and increased the significance of m-ICT in our lives. We now have ondemand access to business processes, projects and the people that affect business progress. Drucker's PC skill-driven future is now echoed by von Koschembahr (2005) whose work emphasizes that, to succeed, knowledge workers need the ability to use $\mathrm{m}$-ICT devices with, or in place of, desktop computers. But if mobile technology is changing business and the skill set to succeed in business, how should business schools adapt to educate effective human capital? In the following section the foundation of the curricular strategy is presented up on which a conceptual framework is built providing the business context for skill development.

Low Application Skills, and the Formation of the Independent Business Unit

Effective skill development requires context in order for the learner to understand the applicability of the skill (Cutler, Fleming, \& Rosenburg, 2000) and for the quality of the performance to be gauged (Jonassen \& Land, 2000). In the business context, skills must be applied to either product or process for the betterment of the enterprise (Noll \& Wilkins, 2002). A truly mobile business has a different operational context than a business that is more traditionally stationary in operations. Both models however, operate with the expectations that employees will act in the interest of the organization. More importantly all businesses expect that their employees have the skills to act in the interest of the organization regardless of the situational demands. This means the ability to take ownership and solve 
problems as they arise using the appropriate soft or hard skills.

Despite the technology enhanced life style of today's college bound youth, research is pointing to the fact that incoming college freshman lack the IT skills to succeed in college (Sherry \& Fielden, 2005) much less to become an independent problem solver in business (Salaway \& Caruso, 2007). Does this techsavvy future workforce have the technology skills necessary to be productive and add value to business? This research acknowledges that Milennials grew up in a world of ever changing technology but are ignorant of how it all works to creates business value or what features differentiate productive technologies from simple gadgetry. Research from Stone and Madigan (2007) concludes that "the ICT skill level of incoming freshmen is often less than is needed for academic success" (p. 76). They point out that the changing workplace is placing increased value on the ability of workers to be effective in technology use upon college graduation (Stone \& Madigan, 2007). Prior to Stone and Madigan, a study of millennial youth in Australia concludes:

The Millennial cohort was only marginally more competent than the older cohorts in word processing, whilst all students were lacking skills in spreadsheets and databases. It would seem that although the Millennial students have been brought up with technology, have access to computers and the latest operating systems, the students in this study have not been exposed to the application programs needed in the business environment (Sherry \& Fielden, 2005, p. 498).

The Sherry \& Fielden (2005) study goes on to suggest that it is important that higher education instructors be aware of the limitations of the Millennials' technological repertoire. The authors disclose that their study sample was largely exchange students from India and the Pacific Rim whose technology experience may not adequately represent other populations. However, their findings are supported elsewhere. An EDUCAUSE study (Caruso, 2005) in 2003 with 4,374 respondents at 13 United States based four-year institutions of higher learning found that despite high levels of technology access and experience, students lacked skills in database, spread sheet and graphical software.

A subsequent study (Salaway \& Caruso, 2007) with 28,486 respondents from over 90 four-year institutions of higher learning found similar results. These studies all point out that university students generally do not use business oriented technologies outside of the institutional setting and therefore depend on the collegiate experience to prepare them for the business world technologically. The key finding of these studies as it relates to this paper is that students depend on the curriculum to prepare them to be effective in their vocations.

Before business schools can effectively teach about, and with $\mathrm{m}$-ICT, faculty and administration must understand the changing expectations and roles of human capital in the business context. The traditional bond of consistent, dependable employment in exchange for loyal and productive work has long been broken (Cooper, 1999). As a downstream effect of this demise, Malone and Laubacher (1998) observed the formation of an 'E-lance' economy where " $[\mathrm{t}]$ asks aren't assigned and controlled through a stable chain of management but rather are carried out autonomously by independent contractors" ( $p$. 146). This productivity model is similar to how motion pictures are created in which experts are plugged into specific roles until the project is completed. Then those experts are free to seek other projects or may work on numerous projects at one time. In order to keep a project pipeline filled while maintaining a particular area of expertise requires nearly constant interaction between multiple sources of specific knowledge. The fluid interaction necessary to act as an independent business unit demands high order mobile productivity skills (Kakihara \& Sørensen, 2002).

Mobile ICT facilitates relatively inexpensive contact to many geographically separated entities either at the same time or asynchronously as needed. Being able to effectively use email, SMS, file transfer, phone and video takes a mobile user to another level of 
accurate and thorough communication. Being able to assess mobile tools for their applicability or weaknesses and having the ability to judge appropriate use of asynchronous and synchronous tools requires intimate market knowledge and business savvy. To marry skillful m-ICT use with well rounded business acumen requires a curricular strategy that integrates both while leaving room for individual innovation.

\section{The M-ICT Curricular Strategy Model}

Many undergraduate and graduate IT curriculums have become out of date with the needs of industry (Medlin, Schneberger, \& Hunsinger, 2007) and out of touch with the technology experience of students (Stone \& Madigan, 2007). Cursory observation of information and communication technology (ICT) reveals a dynamic characteristic making the currency of even the most recently constructed curriculum a challenge. However the need to stay on top of the needs of industry is paramount if the United States is to remain competitive in the global marketplace (Mata, Fuerst, \& Barney, 1995).

The curricular strategy proposed here uses the triad baseline model for training knowledge workers (L. Smith, Hunt, Berry, \& Hunt, 2005) to provide the business context. The triad model is then built upon using the mobility areas proposed by Kakihara and Sørensen (2002). This addition provides the m-ICT focus while maintaining the business role of the technology. Together they form a matrix in which curricular components can be evaluated in consideration of the mobile business context. Furthermore, each cell of the matrix is aligned with the critical core skills recommended by Noll and Wilkins (2002) for IT professionals. This alignment facilitates connection of new m-ICT skills with existing IT core skill areas (see Table 1).

Table 1: Summary matrix of M-ICT curricular strategy areas

\begin{tabular}{|c|c|c|c|}
\hline & Locational & Operational & Interactional \\
\hline Management & $\begin{array}{l}\text { Information/ } \\
\text { Knowledge Management: } \\
\text { Creating a work } \\
\text { environment regardless of } \\
\text { modality through managing } \\
\text { services, resources, and } \\
\text { sessions. }\end{array}$ & $\begin{array}{l}\text { Decision Support Systems } \\
\text { Management: Project } \\
\text { management, team building, } \\
\text { service management, } \\
\text { community formation, } \\
\text { information brokering, and } \\
\text { negotiation skills }\end{array}$ & $\begin{array}{l}\text { End-User Training } \\
\text { Education: Awareness of } \\
\text { barriers and limitations } \\
\text { interaction based on } \\
\text { context. Developing and } \\
\text { maintaining CoPs through } \\
\text { information sharing. }\end{array}$ \\
\hline Technology & $\begin{array}{l}\text { Telecommunication } \\
\text { Fundamentals: Range, } \\
\text { availability, and quality of } \\
\text { service are affected by } \\
\text { location. }\end{array}$ & $\begin{array}{l}\text { Application/Database } \\
\text { Development: Data and } \\
\text { information format } \\
\text { evaluation and application. }\end{array}$ & $\begin{array}{l}\text { Systems Analysis: System } \\
\text { interoperability locally and } \\
\text { globally. }\end{array}$ \\
\hline Communication & $\begin{array}{l}\text { Industry Specific } \\
\text { Knowledge: Awareness of } \\
\text { the contextual nature of } \\
\text { information value. }\end{array}$ & $\begin{array}{l}\text { Business } \\
\text { Communications: Format } \\
\text { and function of each } \\
\text { communication medium and } \\
\text { how it is affected by } \\
\text { interpersonal variables. }\end{array}$ & $\begin{array}{l}\text { Information Access \& IS } \\
\text { Security: Sensitivity to } \\
\text { environmental factors and } \\
\text { how public environments } \\
\text { affects and is affected by } \\
\text { mobile communications. }\end{array}$ \\
\hline
\end{tabular}


In the following paragraphs each mobility area is described within a usage context, of management, technology, or communication. Research by Kakihara (2003) offers general categories of how m-ICT is applied in business by looking first at mobile professional work:

Based on the results, it can be argued that emerging mobile professional work can be analyzed from three interrelated perspectives on mobility: locational mobility concerned with the workers' extensive geographical movement, operational mobility in relation for their capability for flexible operation as an independent unit of business, and interactional mobility associated with their intense and fluid interaction with a wide range of people (Kakihara, 2003, p. 198, italics in original).

These three mobilities offer a conceptual perspective from which to view the formation of skills that are unique to using $\mathrm{m}$-ICT as a productive business tool. But alone, locational, operational, and interactional mobilities do not offer a sufficient business related focus. These mobilities need to be tied to business concepts. To this end, the mobilities are mated in the matrices with the digital skill categories proposed by Smith, Hunt, Berry, and Hunt (2005) for training IT professionals. Combined with the mobility specific areas of interactional, operational, and locational, the Smith, et al. (2005) categories provide a business productivity context for the analysis of curricular changes.

Locational Aspects. Where the end-user is when using the mobile device is as important as what the user is doing with the device while in that location. Additionally, mobile workers often are unable to spend large amounts of time working in a single spot. This issue forces an ability to be able to break work into tasks and using all disposable assets that can be applied in a variety of locations.
- Management of location: Kristoffersen and Ljungberg (1999) identified three distinct modalities that distinguish mobile from stationary work: Visiting is working in different places for a significant period of time; Travelling is working while travelling in a vehicle, such as an airplane or a train; and Wandering is working while being locally mobile. These varying modalities, according to Kristoffersen et al. (1999), require management of services, resources, and sessions to facilitate the formation of a mobile work environment.

- Technology implications: There are a number of environmental factors that will affect the availability and quality of m-ICT services depending on location and distance from service points. It is important to keep in mind that services are two-way, sending and receiving, and therefore location variables may affect end-user flexibility as an independent business unit.

- Communication: The convergence of cellular phones with smart devices introduces another dimension to information managementinformation that is relative to the context. For instance, information that may have no value in a fixed office setting may take on value while in the mobile setting (i.e. what may be advertising in a fixed context may become timely information in the mobile context; see Rheingold, 2002). Additionally, the use of one's mobile device may be dependent on the environment or situation one finds him or herself. Remaining empathetic to the needs of individuals around one and using common sense for safe mobile technology management is all part of remaining effective.

Operational Aspects. Efficient coordination of geographically separated task forces, project teams, and/or virtual corporations requires frequent and useful communication between members regardless of where they are operating. Operational efficiency depends on "establishing flexible organizational and operational structures [which] is of paramount importance for virtually all firms" (Kakihara \& Sørensen, 2002, p. 6).

- Management of operational: Management of operational aspects focuses of collaborative activities (Kakihara \& Sørensen, 2002). For example, project management is based on mutual interdependencies of time, space, personnel and 
budgets. Keeping in touch with information on all these critical areas of projects facilitates operational flexibility and target achievement. Collaboration with experts outside of the community is also important and negotiating access to these experts increases the value of the team and the information the community provides. The value of the information puts independent operators in a strong brokering position (Wagner, 2005).

- Technology implications: Because mobile endusers are a business unit that can be utilized on an on-demand basis it is paramount that device functionality be maintained and that access to important data is secure yet readily retrievable. To accomplish this access, mobile end-users need to be very familiar with numerous data and file formats. Information literacy is knowing how to apply structure to information (Koniger \& Janowitz, 1995). This concept includes knowing that digital content is in many forms, such as raw data, text files (e.g. e-mail), portable digital files (PDF), documents, presentations, web pages, RSS alerts, text messages and audio. To add to the possibilities, any given file can be changed to another form to reduce size or adapt to another operating system platform. In addition, there are a number of peripheral devices that provide hands-free operation which further expands potential locations.

- Communication: Quick mobile applications, such as Simple Messaging System (SMS) or texting can provide the 'glue' to keep members informed and circulate updates and progress (Kakihara \& Sørensen, 2002). SMS use is increasingly being linked with blog sites and other web-based services (e.g. RSS), which can help members maintain access to communities of practice that are not directly connected with the primary community. Maintaining effective communication for flexible operations also requires awareness of the many communication forms offered by m-ICT devices including, email, SMS (texting), beeping, video flashing, multi-way calling, voice mail, and podcasting. The effectiveness of each of these mediums is subject to an effect range influenced by social and psychological dimensions (Sohn \& Lee, 2005). Choosing the most effective medium for the moment depends on the context, sensitivity, and technical competence of both sender and receiver (Sohn \& Lee, 2005).
Interactional Aspects. Because of the nature of the work of mobile professional researchers, they tend to enter into a broader range of social contacts and contexts than do their desk bound counterparts (Ling, 2004). In public and private situations alike, endusers need to be aware of how the context affects content and vice versa. The fluidity of information can be, and often is, taken for granted, and end-users fail to recognize the effect that the use of m-ICT devices may have on the interpersonal environment around them (Nyiri, 2002).

- Management of Interactional: Professionalism does not change due to the absence of office walls. Modern mobile workers need to be aware of how mobile information access is constrained by the tenets professional decorum within a multitude of contexts. Tenets such as meeting deadlines, keeping the clients well informed, and being an effective communicator are all practices that make one effective regardless of location. Interactional aspects may change the boundaries of a community of practice (CoP) as well (Kakihara \& Sørensen, 2002). Lave and Wenger (1991) observe that the boundaries of a community of practice are constantly negotiated and renegotiated, depending on one's understanding and experience within his or her context. Effectively managing this fundamental link to expertise and support is crucial to productivity.

- Technology Implications: Interoperability between systems has traditionally been a concern for business growing businesses with legacy systems, but now it is important for the mobile operator as well. Maintaining a m-ICT device that is capable of full connectivity with target devices, including wireless network access points, cellular carrier resources, and other mICT devices, requires knowledge of telecommunication principles as well as the many carrier voice and data options. For instance, what are the implications of being on a $2 \mathrm{G}, 3 \mathrm{G}$, or $4 \mathrm{G}$ network and how does that connectivity option affect their choice of applications?

- Communication: The mobile phone is "an 'indiscreet' technology, one which leaks the personal into the public" (p. 58) where the intimacy of a phone call is gone and the user in now the target of public inspection (Höflich, 2006). Using mobile technology in public 
requires the skill of negotiating private spaces and an awareness of the cognitive space that the phone creates (Humphreys, 2005). This suggests that m-ICT be used cautiously while in the presence of clients or potential clients as alienation, embarrassment, and breaches of security are at risk.

The contents of each cell in the matrix (see Table 1) will change with the evolution of m-ICT technology. But the mobility characteristics and the focus of enduser application will remain the same. The matrix further illustrates how the union of business productivity categories and unique mobility areas, form a connection where m-ICT skills can be contextualized to facilitate curricular design. The contextualization of skills facilitates scenario driven instruction. Students are better able to see themselves in scenario design thus providing a method fostering critical and creative thinking (Knowles, 1972). Curricular design is beyond the scope of this paper; however, the foundational concepts provided by Smith, et al. (2005):

...more closely resembles an
interactive arrangement of
instruction within a college. Each
department, such as Management,
Information Systems, and Business
Communications, is usually both
detached from a college of business
and part of that same infrastructure.
In this model, each discipline is
depicted as separate, yet totally
connected to a Business Core in
which soft and hard skills,
qualitative and quantitative skills,
and creative and critical thinking
occur. (p. 13).

\section{SUMMARY AND FUTURE RESEARCH}

With doubt, the advent of the personal computer has irrevocably changed business and speed thousands of new markets. As a result it is unthinkable for a fouryear institution of higher learning not to include PC applications in the business curriculum. The PC has now evolved into a tool that stands out distinctively from its predecessors. The wide diffusion of mobile information and communication technologies (m-
ICT) have placed a powerful, feature-rich computing environment in the hands of millions of people around the world. These devices posses the computing power and capability of desktop machines, yet researchers and scholars place little focus on how to use these devices effectively. There seems to be an assumption among educators that students already know how to use computing devices and applications. To some degree and primarily in the case of those born after 1983, this assumption is true. However, in the context of business, research has found that students are ill-prepared to bring the features of either PC-based or mobile PC-based business applications to bear on issues of productivity and effective solution design.

Higher education needs to focus its resources on mICT as it has for the desktop computer. Students require instruction in skills necessary to manage $\mathrm{m}$ ICT for both business and personal productivity. The uniqueness of m-ICT device usage is unparalleled because computing devices have never been very mobile. Just like PC management, m-ICT requires effective resource management, technical expertise, and quality communication skills. Now, however, these skills have additional dimensions that affect effective use. To help classify these unique dimensions, the mobile areas of locational, operational, and interactional are cross-referenced with the business solution oriented contexts of management, technology, and communications. By combining the mobility classifications with business contextualization, a $3 \times 3$ matrix is formed in which skills can be placed and understood as to their uniqueness and their varied impact on mobile business operations.

While much research discusses the changes m-ICT brings to the work world and personal life, there is little that suggests how m-ICT tools should be effectively used to maximize resources and achieve organizational and personal goals. There is a need for IT and educational researchers to address issues of best practices, information management, hardware design, and how personal and business productivity is blending. The knowledge economy is breeding a new type of worker that is considered an individual business unit that plugs into projects based on areas of expertise. 
Today's students need to develop their expertise with social networks, communities of practice, graphical and textual communication and realize how being mobile affects their actions and the actions of others in these areas. Research is needed to define effective mobile use in the emerging and varied environments of the mobile professional. Research is also needed in the area of mobile learning and training so expertise can be provided on mobile devices in a justin-time method. Investigations might also look more into how m-ICT is employed differently by different industries and cultures or how the value of information can be assessed if the life of the information is compressed by mobility.

\section{REFERENCES}

Al-Qirim, N. A. (2006). The adoption and usage of mobile and wireless technologies in Small to Medium-Sized Enterprises: A meta model for development. World Review of Science, Technology, and Sustainable Development, 3(2), 123-136.

Brown, A. (2006). Report Highlight for Dataquest Insight: Mobile Phones Set to Become Home Network Devices (Report Highlight No. G00145518): Gartner Research.

Caruso, J. B. (2005). ECAR study of students and information technology, 2004: Convenience, connection, and control. Educause Review, 25 .

Castells, M. (2001). The Internet galaxy: Reflections on the Internet, business, and society. New York: Oxford University Press.

Cheney, P., Hale, D., \& Kasper, G. (1990). Knowledge, skills and abilities of information systems professionals: Past, present and future. Information Management, 9(4), 237-247.

Computer Weekly. (2002). Mobile skills are key to the future. Computer Weekly, 24.

Constantiou, I. D., Damsgaard, J., \& Knutsen, L. (2007). The Four Incremental Steps Toward

Volume XI, No. 2, 2010
Advanced Mobile Service Adoption. Communications of the ACM, 50(6), 51-55.

Cooper, C. L. (1999). Can we live with the changing nature of work? Journal of Managerial Psychology, 14(7/8), 569-572.

Cozza, R. (2007). Report Highlight for Dataquest Insight: Worldwide PDA and Smartphone Shipments Soar $45.7 \%$ in 2Q07 [Electronic Version]. Gartner Media Relations. Retrieved 6/8/08.

Cutler, T., Fleming, D., \& Rosenburg, J. (2000). Skills $x$ knowledge $=$ growth. Melbourne, Australia: Multimedia Victoria.

Dulaney, K., Hart, T. J., Jones, N., \& Basso, M. (2008). Predicts 2009: Mobile and Wireless Continue to Mature (Research Report): Gartner Research.

Farwell, D., Lee, D. M., \& Truath, E. M. (1995). Critical Skills and Knowledge Requirements of IS Professionals: A Joint Academic/Industry Investigation. MIS Quarterly, 313-337.

Hart, T. J. (2005). Forecast: Mobile Services, North America, 2000-2009 (Executive Summary): Gartner Research.

Hoffman, M., \& Blake, J. (2003). Computer literacy: today and tomorrow. Journal of Computing Sciences in Colleges, 18(5), 221-233.

Höflich, J. R. (2006). The Mobile Phone and the Dynamic between Private and Public Communication: Results of an International Exploratory Study. Knowledge, Technology \& Policy, 19(2), 58-68.

Horrigan, J. B. (2007). A Typology of Information and Communication Technology Users (Report): Pew Reseach.

Humphreys, L. E. E. (2005). Social Topography in a Wireless Era: The Negotiation of Public and Private Space. Journal of Technical Writing \& Communication, 35(4), 367-384. 
Jonassen, D. H., \& Land, S. M. (2000). Theoretical foundations of learning environments. Mahwah, N.J.: L. Erlbaum Associates.

Kakihara, M. (2003). Emerging Work Practices of ICT-Enabled Mobile Professionals. Unpublished Dissertation, University of London-London School of Economics.

Kakihara, M., \& Sørensen, C. (2002). Post-Modern Professionals Work and Mobile Technology. Paper presented at the Proceedings of the 25th Information Systems Research Seminar (IRIS 25), Scandinavia

Kim, H., Knight, D. K., \& Crutsinger, C. (2009). Generation Y employees' retail work experience: The mediating effect of job characteristics. Journal of Business Research, 62(5), 548-556.

Knowles, M. S. (1972). Toward a model of lifelong education. Washington, D.C.: ERIC.

Koniger, P., \& Janowitz, K. (1995). Drowning in information, but thirsty for knowledge. International Journal of Information Management, 15(1), 5-16.

Kristofferson, S., \& Ljungberg, F. (1999). Innovation of IT Use in Mobile Settings. SIGCHI Bulletin, 31(1), 29-34.

Lave, J., \& Wenger, E. (1991). Situated learning: Legitimate peripheral participation. Cambridge, UK: Cambridge.

Leitheiser, R. L. (1992). MIS Skills for the 1990s: A Survey of MIS Managers' Perceptions. Journal of Management Information Systems, 9(1, Summer), 69-91.

Ling, R. S. (2004). The mobile connection : the cell phone's impact on society. San Francisco, CA: Morgan Kaufmann.

Malone, T. W., \& Laubacher, R. J. (1998). The Dawn of the E-lance Economy. Harvard Business Review, 76(5), 144-152.
Mata, F. J., Fuerst, W. L., \& Barney, J. B. (1995). Information Technology and Sustained Competitive Advantage: A Resource-Based Analysis. MIS Quarterly, 19(4), 487-505.

Mearian, L. (2008). Mobile hardware outpaces software, user capabilities. Computerworld, 42(37), 1.

Medlin, B. D., Schneberger, S., \& Hunsinger, D. S. (2007). Perceived Technical Information Technology Skill Demands Versus Advertised Skill Demands:An Empirical Study. Journal of Information Technology Management, 18(3-4).

Mintel. (2005). Technological advances drive demand for mobile content: Mintel International Group Limited.

Nelson, R. R. (1991). Educational Needs as Perceived by IS and End-user Personnel: A Survey of Knowledge and Skill Requirements. MIS Quarterly, $15(4$ (December)), 503-521.

Noll, C. L., \& Wilkins, M. (2002). Critical Skills of IS Professionals: A Model for Curriculum Development. Journal of Information Technology Education, 1(3), 143-154.

Nyiri, K. (2002). Towards a philosophy of $m$ learning. Paper presented at the Wireless and Mobile Technologies in Education, 2002. , Hungary.

Oronsky, C. R., \& Chathoth, P. K. (2007). An exploratory study examining information technology adoption and implementation in full-service restaurant firms. International Journal of Hospitality Management, 26(4), 941-956.

Pearlson, K., \& Saunders, C. S. (2004). Managing and using information systems : a strategic approach (2nd ed.). Hoboken, NJ: Wiley.

Pew Research Center. (2010, February). Millenials: Confident. Connected. Open to Change. 
Washington, DC: Pew Research Center for the People \& the Press.

Raine, L. (2006). Digital 'Natives' Invade the Workplace [Electronic Version]. Pew Internet \& American Life Project, 5. Retrieved 6/9/08 from http://www.pewinternet.org/ppt/New\%20W orkers\%20--

$\% 20$ pewresearch.org\%20version\%20_final_ .pdf.

Rogers, E. M. (1983). Diffusion of innovations (3rd ed.). New York, N.Y.: Free Press ; Collier Macmillan.

Salaway, G., \& Caruso, J. B. (2007). The ECAR Study of Undergraduate Students and Information Technology, 2007. Educause Review, 6, 124.

Shaw, S., \& Fairhurst, D. (2008). Engaging a new generation of graduates. Education + Training, 50(5), 366 - 378.

Sherry, C. A., \& Fielden, K. A. (2005). The millennials: Computer savvy (or not?). Paper presented at the Higher Education Research and Development Society of Australia, Sydney, AU.

Smith, H., \& Fingar, P. (2003). Business Process Management: The Third Wave.

Smith, L., Hunt, C. S., Berry, R., \& Hunt, D. (2005). An Integrated IT Curriculum Model for Advancing Education in Information Technologies, Learning, and Performance. Information Technology, Learning and Performance Journal Special Issue, 23(3).

Sohn, D., \& Lee, B. (2005). Dimensions of interactivity: Differential effects of social and psychological factors. Journal of Computer-Mediated Communication, 10(3), article 6 .
Stone, J. A., \& Madigan, E. (2007). Inconsistencies and Disconnects. Communications of the ACM, 50(4), 76-79.

von Koschembahr, C. (2005). Optimizing Your Sales Workforce through Mobile Learning. American Society for Training and Development, 14, 2005.

Wagner, E. D. (2005). Enabling mobile learning. EDUCAUSE Review, 40(3), 40-53.

Webb, R. (2008). Mobile data card sales nearly quadrupling, data subscribers to hit $144 \mathrm{M}$ by 2011: Infonetics Research.

Winter, H. (2008). Gartner Says Worldwide Mobile Phone Sales Increased 16 Per Cent in 2007 [Electronic Version]. Gartner Media Relations, 2008 Press Release. Retrieved 6/8/08 from http://www.gartner.com. 